University of Nebraska - Lincoln

DigitalCommons@University of Nebraska - Lincoln

West Central Research and Extension Center, North Platte

Agricultural Research Division of IANR

1986

\title{
SEROSURVEY FOR SELECTED PATHOGENS IN HUNTER-KILLED PRONGHORNS IN WESTERN NEBRASKA
}

Jerre L. Johnson

University of Nebraska West Central Research and Extension Center, North Platt

T. Lynwood Barber

ARS, USDA, Denver

Merwin L. Frey

University of Nebraska-Lincoln,

George Nason

Nebraska Game and Parks Commission

Follow this and additional works at: https://digitalcommons.unl.edu/westcentresext

Part of the Agriculture Commons

Johnson, Jerre L.; Barber, T. Lynwood; Frey, Merwin L.; and Nason, George, "SEROSURVEY FOR SELECTED PATHOGENS IN HUNTER-KILLED PRONGHORNS IN WESTERN NEBRASKA" (1986). West Central Research and Extension Center, North Platte. 8.

https://digitalcommons.unl.edu/westcentresext/8

This Article is brought to you for free and open access by the Agricultural Research Division of IANR at DigitalCommons@University of Nebraska - Lincoln. It has been accepted for inclusion in West Central Research and Extension Center, North Platte by an authorized administrator of DigitalCommons@University of Nebraska - Lincoln. 


\title{
SEROSURVEY FOR SELECTED PATHOGENS IN HUNTER-KILLED PRONGHORNS IN WESTERN NEBRASKA
}

\author{
Jerre L. Johnson,' T. Lynwood Barber, ${ }^{2}$ Merwin L. Frey, ${ }^{3}$ and George Nason 4
}

ABSTRACT: Exposure of pronghorns (Antilocapra americana) in western Nebraska in 1983 to selected livestock pathogens was examined by serology and attempted virus isolation. Antibodies were present to the agents of bluetongue, epizootic hemorrhagic disease, and bovine respiratory syncytial virus. There were no serologic reactors to Brucella, and attempts to isolate the viruses of bluetongue and epizootic hemorrhagic disease were negative.

\section{INTRODUCTION}

Brucellosis (Kruse, pers. comm.), infections with bluetongue virus (BTV) (Jaggers, 1984), and bovine respiratory syncytial virus (BRSV) (Johnson et al., 1982; Frey, 1983) are problems in cattle herds of western Nebraska. Epizootic hemorrhagic disease (EHD) is known to be a sporadic problem in deer in Nebraska (Wilhelm and Trainer, 1966). The purpose of this study was to determine the prevalence of these disease agents in pronghorn in western Nebraska.

Serologic studies in wild ruminants conducted on numerous occasions throughout the United States (Hoff et al., 1972, 1973; Kistner et al., 1975; Adrian and Keiss, 1977) have shown that pronghorn may serve as sentinels or reservoirs for certain cattle diseases (Trainer, 1970). The largest pronghorn population in Nebraska is in the Panhandle, or northwestern counties. Mingling with cattle is common because approximately $90 \%$ of the pronghorn rangeland is on private ranches.

Received for publication 18 December 1984.

' University of Nebraska West Central Research and Extension Center, North Platte, Nebraska 69101, USA.

${ }^{2}$ Arthropod-borne Animal Diseases Research Laboratory, ARS, USDA, Denver, Colorado 80225, USA

${ }^{3}$ University of Nebraska-Lincoln, Lincoln, Nebraska 68583, USA.

- Game and Parks Commission, North Platte, Nebraska 69101, USA.

\section{MATERIALS AND METHODS}

\section{Collection of samples}

In 1983 a letter and card were sent to the 1,040 pronghorn permit holders requesting cooperation in collecting blood samples at the kill site. Five hundred and sixty responded favorably and were mailed a carton containing two vacutainer tubes, one heparinized and one plain, with instructions and a return mailing address. Hunter permit numbers were written on the return mailing carton which was either to be mailed to the West Central Research and Extension Center or deposited at a Game and Parks check station. Permit numbers were used to retrieve kill data stored by the Game and Parks Department. Samples were received, processed, and frozen at the West Central Center.

\section{Serology}

Bluetongue and EHD serology and virus isolations were conducted at the United States Department of Agriculture, Agricultural Research Service, Arthropod-borne Animal Diseases Research Laboratory in Denver, Colorado. Antibody to BTV was determined by the immunodiffusion test and antibody to EHD by the plaque reduction neutralization test (Jochim and Jones, 1976; Barber and Collisson, 1983). Samples for BRSV were tested at the Veterinary Science Department at the University of $\mathrm{Ne}$ braska, Lincoln, Nebraska. A microtitration serum-virus neutralization test was used that differed from standard neutralization tests primarily in having increased buffers $(10 \mathrm{mM}$ each of HEPES (N-2-hydroxyethylpiperazine$\mathrm{N}^{\prime}$-2-ethanesulfonic acid), EPPS (N-[2-hydroxyethyl]-piperazine- $N^{\prime}-3$-propanesulfonic acid; HEPPS), and MOPS (3-[N-morpholino]-propanesulfonic acid), and $2 \mathrm{mM}$ of $\mathrm{NaHCO}_{3}$ ), maintenance serum (final, 10\% horse serum), and virus (approximately $10^{3}$ plaque-forming units per well). 
TABLE 1. Prevalence of antibodies to bovine respiratory syncytial virus in pronghorns in Nebraska by age and sex, 1983.

\begin{tabular}{|c|c|c|c|c|c|c|c|c|c|c|}
\hline \multirow[b]{2}{*}{ Sex } & \multirow[b]{2}{*}{ Total } & \multirow[b]{2}{*}{ Fawn } & \multirow[b]{2}{*}{ Unknown } & \multicolumn{7}{|c|}{ Age (yr) } \\
\hline & & & & 1 & 2 & 3 & 4 & 5 & 6 & 7 \\
\hline $\begin{array}{l}\text { Male } \\
\text { Percent }\end{array}$ & $\begin{array}{l}55 / 102 \\
54 \%\end{array}$ & $\begin{array}{l}2 / 3 \\
67 \%\end{array}$ & $\begin{array}{l}19 / 39 \\
49 \%\end{array}$ & $\begin{array}{l}15 / 26 \\
58 \%\end{array}$ & $\begin{array}{l}6 / 16 \\
38 \%\end{array}$ & $\begin{array}{r}4 / 5 \\
80 \%\end{array}$ & $\begin{array}{l}2 / 5 \\
40 \%\end{array}$ & $\begin{array}{l}0 / 0 \\
0 \%\end{array}$ & $\begin{array}{l}0 / 1 \\
0 \%\end{array}$ & $\begin{array}{r}1 / 1 \\
100 \%\end{array}$ \\
\hline $\begin{array}{l}\text { Female } \\
\text { Percent }\end{array}$ & $\begin{array}{l}11 / 19 \\
58 \%\end{array}$ & $\begin{array}{c}1 / 1 \\
100 \%\end{array}$ & $\begin{array}{c}3 / 4 \\
75 \%\end{array}$ & $\begin{array}{r}3 / 5 \\
60 \%\end{array}$ & $\begin{array}{c}3 / 4 \\
75 \%\end{array}$ & $\begin{array}{l}0 / 1 \\
0 \%\end{array}$ & $\begin{array}{c}1 / 4 \\
25 \%\end{array}$ & $\begin{array}{l}0 / 0 \\
0 \%\end{array}$ & $\begin{array}{l}1 / 1 \\
100 \%\end{array}$ & $\begin{array}{l}0 / 0 \\
0 \%\end{array}$ \\
\hline $\begin{array}{l}\text { Total } \\
\text { Percent }\end{array}$ & $\begin{array}{l}66 / 121 \\
55 \%\end{array}$ & $\begin{array}{c}3 / 4 \\
75 \%\end{array}$ & $\begin{array}{l}22 / 43 \\
51 \%\end{array}$ & $\begin{array}{l}18 / 31 \\
58 \%\end{array}$ & $\begin{array}{l}9 / 20 \\
45 \%\end{array}$ & $\begin{array}{l}4 / 6 \\
67 \%\end{array}$ & $\begin{array}{r}3 / 9 \\
33 \%\end{array}$ & $\begin{array}{l}0 / 0 \\
0 \%\end{array}$ & $\begin{array}{c}1 / 2 \\
50 \%\end{array}$ & $\begin{array}{r}1 / 1 \\
100 \%\end{array}$ \\
\hline
\end{tabular}

- No. positive/no examined.

Serum samples were tested for Brucella antibodies at the State-Federal Laboratory in Lincoln, Nebraska using the acidified plate method (Alton et al., 1975)

\section{Viral assay}

Heparinized blood samples were assayed for BTV by subculture in embryonated chicken eggs and BHK-21 cell culture as described (Barber and Collisson, 1983).

\section{RESULTS}

The hunter response to the mail sampling was excellent. Five hundred and sixty mailers were sent out. The return rate of mailers exceeded $80 \%$, with $64 \%$ usable samples. However, there was a discrepancy between the samples tested for the four diseases due to the condition and quantity of blood serum.

None of the 233 samples suitable for Brucella testing were positive. Serologic testing of pronghorn samples resulted in $27 \%$ with positive reactions to BTV, $30 \%$ to EHDV, and 55\% to BRSV (Tables 13). The BRSV titers ranged from less than 1:5 to 1:160. Twenty-three percent of the animals were positive to both EHDV and BTV, $18 \%$ to EHDV and BRSV, and $16 \%$ to BTV and BRSV. Fourteen percent were positive to BTV, EHDV, and BRSV.

Due to hunter preference of taking males over females, no pattern related to sex could be determined but there was variation due to age. Nineteen percent of the fawns and 1-yr-old animals were positive for BTV while $43 \%$ of the 2- to $7-y r$ - old animals were seropositive for BTV (Table 2). This pattern was similar in EHDV with $20 \%$ of the fawns and 1-yrolds seropositive to EHDV compared to $51 \%$ of the 2- to $7-y r$-old pronghorns being positive for EHDV.

Isolation attempts for BTV and EHDV were negative for all 342 samples.

\section{DISCUSSION}

The presence of serologic reactors indicates a certain percentage of the animals have been exposed to agents which may be related to or identical to three of the four livestock pathogens used as standards in these serologic tests. Documentation of reactors alone does not provide evidence of pathogenicity or transmission of pathogens between wildlife and livestock (Stauber et al., 1980).

Our BTV results are similar to those in Wyoming and Colorado (Trainer and Jochim, 1969) in that the prevalences of antibodies correlate with those of the cattle population. A 1983 cattle survey of $4 \%$ of the herds in the Panhandle area revealed $28 \%$ of the animals positive by the bluetongue immunodiffusion test (Jaggers, 1984). Positive serology reported herein was not associated with clinical disease or with bluetongue lesions in dead pronghorn routinely reported by the Game and Parks Department (Hoff and Trainer, 1972; Kistner et al., 1975). The number of animals seropositive for EHDV was higher 
TARLE 2. Prevalence of antibodies to bluetongue virus in pronghorns in Nebraska by age and sex, 1983.

\begin{tabular}{|c|c|c|c|c|c|c|c|c|c|c|}
\hline \multirow[b]{2}{*}{ Sex } & \multirow[b]{2}{*}{ Total } & \multirow[b]{2}{*}{ Fawn } & \multirow[b]{2}{*}{ Unknown } & \multicolumn{7}{|c|}{ Age (yr) } \\
\hline & & & & 1 & 2 & 3 & 4 & 5 & 6 & 7 \\
\hline $\begin{array}{l}\text { Male } \\
\text { Percent }\end{array}$ & $\begin{array}{l}72 / 275 \\
26 \%\end{array}$ & $\begin{array}{l}0 / 7 \\
0 \%\end{array}$ & $\begin{array}{l}33 / 139 \\
24 \%\end{array}$ & $\begin{array}{l}11 / 63 \\
17 \%\end{array}$ & $\begin{array}{l}11 / 34 \\
32 \%\end{array}$ & $\begin{array}{l}6 / 15 \\
40 \%\end{array}$ & $\begin{array}{l}10 / 13 \\
77 \%\end{array}$ & $\begin{array}{c}1 / 2 \\
50 \%\end{array}$ & $\begin{array}{l}0 / 1 \\
0 \%\end{array}$ & $\begin{array}{l}0 / 1 \\
0 \%\end{array}$ \\
\hline $\begin{array}{l}\text { Female } \\
\text { Percent }\end{array}$ & $\begin{array}{l}20 / 64 \\
31 \%\end{array}$ & $\begin{array}{l}1 / 6 \\
17 \%\end{array}$ & $\begin{array}{l}6 / 29 \\
21 \%\end{array}$ & $\begin{array}{l}4 / 8 \\
50 \%\end{array}$ & $\begin{array}{c}2 / 9 \\
22 \%\end{array}$ & $\begin{array}{c}2 / 3 \\
67 \%\end{array}$ & $\begin{array}{l}2 / 5 \\
40 \%\end{array}$ & $\begin{array}{l}1 / 1 \\
100 \%\end{array}$ & $\begin{array}{l}2 / 2 \\
100 \%\end{array}$ & $\begin{array}{l}0 / 1 \\
0 \%\end{array}$ \\
\hline $\begin{array}{l}\text { Total } \\
\text { Percent }\end{array}$ & $\begin{array}{l}92 / 339 \\
27 \%\end{array}$ & $\begin{array}{l}1 / 13 \\
0.08 \%\end{array}$ & $\begin{array}{l}39 / 168 \\
23 \%\end{array}$ & $\begin{array}{l}15 / 71 \\
21 \%\end{array}$ & $\begin{array}{l}13 / 43 \\
30 \%\end{array}$ & $\begin{array}{l}8 / 18 \\
44 \%\end{array}$ & $\begin{array}{l}12 / 18 \\
67 \%\end{array}$ & $\begin{array}{l}2 / 3 \\
67 \%\end{array}$ & $\begin{array}{l}2 / 3 \\
67 \%\end{array}$ & $\begin{array}{l}0 / 2 \\
0 \%\end{array}$ \\
\hline
\end{tabular}

- No. positive/no. examined

than anticipated when compared to 1983 EHDV/BTV deer mortality reports (Schildman, 1983).

Both BTV and EHDV appear to be enzootic in the pronghorn population because of the positive correlation between higher prevalences of antibody and increasing ages of animals (Tables 2,3 ). There were no significant differences correlated with the sex of the pronghorns. Both viruses showed the greatest prevalence of antibodies in the 3- to 6-yr-old animals where $57 \%$ had titers to BTV and $62 \%$ to EHDV. These high percentages are indicative of constant cycling of the viruses among the population in an enzootic situation.

Comparing our results with previous serologic studies, the negative findings for Brucella were not surprising (Adrian and Keiss, 1977; Moore and Schnurrenberger, 1981). The Nebraska State Veterinarian's office reports the prevalence of brucellosis in cattle in these same counties to be less than $0.1 \%$ (Kruse, pers. comm.).

The prevalence of BRSV antibodies compares favorably with the high prevalence of BRSV in Nebraska's cattle population (Johnson et al., 1982; Frey, 1983). The positive findings, although not previously reported, were not totally unexpected as results from previous serologic investigations were positive for other bovine respiratory viruses (Stauber et al., 1980). What was surprising was the number of titers in the pronghorn samples above 1:10. This represents natural exposure as BRSV vaccine for cattle was not marketed at the time this survey was taken. An endemic condition exists in the pronghorn as $60 \%$ of the fawns and $1-\mathrm{yr}$ old animals and $51 \%$ of the 2- to 7 -yr-old pronghorns had antibodies to BRSV. To maintain antibodies to BRSV in adult animals, a continuous circulation of the virus needs to exist in partially immune adults,

TABLE 3. Prevalence of antibodies to epizootic hemorrhagic disease virus in pronghorns in Nebraska by age and sex, 1983.

\begin{tabular}{lccccccccccc}
\hline & & & & \multicolumn{7}{c}{ Age (yr) } \\
\cline { 7 - 12 } \multicolumn{1}{c}{ Sex } & Total & Fawn & Unknown & 1 & 2 & 3 & 4 & 5 & 6 & 7 \\
\hline Male & $83 / 275$ & $0 / 7$ & $35 / 139$ & $13 / 63$ & $16 / 34$ & $8 / 15$ & $10 / 13$ & $1 / 2$ & $0 / 1$ & $0 / 1$ \\
Percent & $30 \%$ & $0 \%$ & $25 \%$ & $21 \%$ & $47 \%$ & $53 \%$ & $77 \%$ & $50 \%$ & $0 \%$ & $0 \%$ \\
Female & $20 / 63$ & $1 / 5$ & $7 / 29$ & $3 / 8$ & $2 / 9$ & $2 / 3$ & $2 / 5$ & $1 / 1$ & $2 / 2$ & $0 / 1$ \\
Percent & $32 \%$ & $20 \%$ & $24 \%$ & $38 \%$ & $22 \%$ & $67 \%$ & $40 \%$ & $100 \%$ & $100 \%$ & $0 \%$ \\
Total & $103 / 338$ & $1 / 13$ & $42 / 168$ & $16 / 71$ & $18 / 43$ & $10 / 18$ & $12 / 18$ & $2 / 3$ & $2 / 3$ & $0 / 2$ \\
Percent & $30 \%$ & $0.08 \%$ & $25 \%$ & $23 \%$ & $42 \%$ & $56 \%$ & $67 \%$ & $67 \%$ & $67 \%$ & $0 \%$ \\
\hline
\end{tabular}

- No. positive/no. examined. 
or re-infection of immune deficient pronghorns with multiplication and shedding of the virus. In bovine calves, transmission can occur through infected colostrum (Woods, 1974). These animals would become serologically positive. The persistence of maternal antibodies would depend on the level of immunity of the dam, but titers could be boostered by re-infection. This could also occur in the pronghorns.

The BTV, EHDV, and Brucella results are similar to the results in domestic cattle populations. While the prevalence of BRSV antibody in pronghorn is similar to the prevalence in cattle, it raises questions as to species susceptibility, respiratory disease interactions, and transmission of the virus between the cattle and pronghorn populations.

\section{ACKNOWLEDGMENTS}

The authors wish to express appreciation to David King at the Livestock Disease Control Laboratory for the serologic testing for Brucel$l a$, to the many agents of the Game and Parks Commission for helping to collect blood samples, and to Ellen Heil and Annette Kosmicki for assisting in data accumulation.

\section{LITERATURE CITED}

ADRIAN, W. J., AND R. E. KEISS. 1977. Survey of Colorado's wild ruminants for serologic titers to brucellosis and leptospirosis. J. Wildl. Dis. 13: 429-431.

Alton, G. G., L. M. Jones, And D. E. Pietz. 1975. Laboratory Techniques in Brucellosis, 2nd Ed. World Health Organization, Geneva, Switzerland, Monogr. Ser. No. 55, 163 pp.

Barber, T. L., AND E. W. Collisson. 1983. Implications of a new bluetongue serotype for the U.S. livestock industry. Proc. U.S. Anim. Health Assoc. 87: 90-104.

FREY, M. L. 1983. Bovine respiratory syncytial virus and acute respiratory distress syndrome in cattle. Bovine Pract. 18: 73-77.
Hoff, G. L., L. A. Griner, and D. O. Trainer. 1973. Bluetongue virus in exotic ruminants. J. Am. Vet. Med. Assoc. 163: 565-567.

, AND D. O. Trainer. 1972. Bluetongue virus in pronghorn antelope. Am. J. Vet. Res. 35: 1013-1016.

JAGGERS, R. 1984. Everything you ever wanted to know about bluetongue and less. Proc. Neb. Vet. Med. Assoc. Annu. Mtg., pp. 66-73.

JoChim, M. M., AND S. C. Jones. 1976. Plaque neutralization of bluetongue virus and epizootic hemorrhagic disease virus in $\mathrm{BHK}_{\mathbf{2 1}}$ cells. Am. J. Vet. Res. 37: 1345-1347.

Johnson, J. L., J. L. POMmer, D. B. Hudson, AND A. R. Doster. 1982. Pulmonary emphysema in weaned calves: Laboratory diagnosis. Proc. Annu. Conv. Am. Assoc. Bovine Pract. 14: 122126.

Kistner, T. P., G. E. Reynolds, L. D. Koller, C. E. Trainer, and D. L. Eastman. 1975. Clinical and serological findings on the distribution of bluetongue and epizootic hemorrhagic disease virus in Oregon. Proc. Annu. Mtg. Am. Assoc. Vet. Lab. Diag. 18: 135-148.

MoORE, C. G., AND P. R. SCHNURRENBERGER. 1981. A review of naturally occurring Brucella abortus infections in wild mammals. J. Am. Vet. Med. Assoc. 179: 1105-1112.

SChILdman, G. 1983. Wildlife disease and mortality investigations. Nebraska Game Parks Comm. Work Plan S-83. Pittman-Robertson Proj. W-15R-40, 17 pp.

Stauber, E. K., R. Autenrieth, O. D. MARKhaM, AND U. WHITBECK. 1980. A seroepidemiologic survey of three pronghorn (Antilocapra americana) populations in southeastern Idaho 19751977. J. Wildl. Dis. 16: 109-115.

TRAINER, D. O. 1970. The use of wildlife to monitor zoonoses. J. Wildl. Dis. 6: 397-40l.

$\longrightarrow$, AND M. M. JOCHIM. 1969. Serologic evidence of bluetongue in wild ruminants in North America. Am. J. Vet. Res. 30: 2007-2011.

Wilhelm, A. R., AND D. O. Trainer. 1966. A serological study of EHD of deer. J. Wildl. Manage. 30: 777-780.

Woods, G. T. 1974. Bovine parvovirus I, bovine syncytial virus, and bovine respiratory syncytial virus and their infections. Adv. Vet. Sci. Comp. Med. 18: 273-286. 